\title{
Housekeeping Gene Expression in Bovine Liver is Affected by Physiological State, Feed Intake, and Dietary Treatment ${ }^{1}$
}

\author{
N. A. Janovick-Guretzky, H. M. Dann, ${ }^{2}$ D. B. Carlson, ${ }^{3}$ M. R. Murphy, J. J. Loor, and J. K. Drackley ${ }^{4}$ \\ Department of Animal Sciences, University of Illinois, Urbana 61801
}

\section{ABSTRACT}

Selection of appropriate housekeeping genes (HKG) for normalization of quantitative PCR data for genes of interest is critical for interpretation of results. Ideally, copy number of the chosen HKG mRNA will not vary with experimental treatments or physiological state in the tissue studied, which improves accuracy in detecting changes in genes of interest. Because of the liver's dynamic role in metabolism, physiological state or dietary treatments could alter mRNA expression of commonly used HKG. Therefore, the objective of this study was to evaluate stability of mRNA expression for a number of candidate HKG in bovine liver across different physiological and dietary experimental conditions during the periparturient period. A publicly available program (geNorm) was used to evaluate expression stability of $8 \mathrm{HKG}$ ( $\beta$-actin, glyceraldehyde 3 -phosphate dehydrogenase, $\beta$-glucuronidase, peptidylprolyl isomerase A, polyubiquitin, ribosomal protein S9, ribosomal protein L32, and $18 \mathrm{~S}$ ribosomal RNA) in 91 liver RNA samples. Screened samples included liver from cows in 3 groups: 1) cows receiving a dietary supplement pre- and postpartum ( $\mathrm{n}=10) ; 2)$ cows with clinical or subclinical ketosis $(\mathrm{n}=7)$; and 3 ) cows consuming different amounts of energy prepartum $(n=74)$. In group 3 , samples from $\mathrm{d}-65,-30,-14,1,14,28$, and 49 relative to parturition were included to enable characterization of HKG mRNA expression across different physiological states. Initial analyses indicated that mRNA for ribosomal protein S9 (RPS9) was one of the most stably expressed across different experiment types. To determine the best gene, 200 bootstrap repli-

Received October 3, 2006.

Accepted January 12, 2007.

${ }^{1}$ Supported by USDA Section 1433 Animal Health \& Disease funds appropriated to the Illinois Agricultural Experiment Station. N. A. Janovick-Guretzky was supported by the David H. Baker Graduate Research Fellowship, University of Illinois.

${ }^{2}$ Current address: William H. Miner Agricultural Research Institute, Chazy, NY 12921.

${ }^{3}$ Current address: Department of Animal and Range Sciences, North Dakota State University, Fargo 58105.

${ }^{4}$ Corresponding author: drackley@uiuc.edu cations of the original data set were performed to determine if the ranking of RPS9 was superior to the other 7 genes evaluated. Average ranks and estimated standard errors for the top 3 genes were $1.64 \pm 0.06,3.27$ \pm 0.10 , and $3.71 \pm 0.12$ for RPS9, GAPDH, and $\beta$-actin, respectively. Ribosomal protein $\mathrm{S} 9$ was ranked first $59 \%$ of the time and was never ranked lower than fifth. The lowest-ranked gene was polyubiquitin, ranked last $46.5 \%$ of the time (average rank $=6.85 \pm 0.10$ ). In this study, physiological state, amount of intake, or dietary treatment influenced the mRNA expression of commonly used HKG in bovine liver. Ideally, expression stability should be tested before collection of data in all experiments; however, we have shown that RPS9 mRNA is stable across several physiological and dietrelated experimental conditions for dairy cows, making it a good HKG in liver quantitative PCR experiments. Key words: liver, housekeeping gene, quantitative polymerase chain reaction

\section{INTRODUCTION}

Quantitative real-time PCR ( $\mathbf{Q P C R})$ characterization of selected mRNA has become a popular method to study changes in relative copy number of mRNA in a variety of tissues and experimental settings. As summarized by Wong and Medrano (2005), qPCR is more sensitive than RNase protection assays, is less variable than band densitometry or probe hybridization as used with end-point assays, and can detect very small copy numbers for mRNA of interest. Because of its sensitivity, a stably expressed internal control gene, or housekeeping gene (HKG), is needed to accurately estimate copy number for mRNA. The expression of an "ideal" HKG will not vary with treatment or physiological state in the tissue studied (Thellin et al., 1999; Bustin, 2000, 2002). Expression of many of the common HKG currently used in experiments, however, varies with treatment or physiological state (Bustin, 2002; Wong and Medrano, 2005). As concerns about normalization to proper HKG have increased, methods to find HKG that are stably expressed under various experimental conditions and tissues of interest have received 
Table 1. Characteristics of liver RNA samples used for real-time quantitative PCR analysis of potential housekeeping genes

\begin{tabular}{|c|c|c|c|c|c|}
\hline $\begin{array}{l}\text { Sample } \\
\text { set }\end{array}$ & $\begin{array}{l}\text { Source of } \\
\text { liver tissue }\end{array}$ & Physiological state & $\mathrm{DRTP}^{1}$ & Dietary treatments ${ }^{2}$ & $\underset{\mathrm{n}}{\text { Samples, }}$ \\
\hline 1 & Dann et al. $(2006)^{3}$ & $\begin{array}{l}\text { Dry } \\
\text { Dry } \\
\text { Dry } \\
\text { Parturition/very early } \\
\text { lactation } \\
\text { Lactating } \\
\text { Lactating } \\
\text { Lactating }\end{array}$ & $\begin{array}{l}-65 \\
-30 \\
-14\end{array}$ & $\begin{array}{l}\text { Limited energy intake prepartum } \\
\text { Ad libitum, limited, or restricted energy intake prepartum } \\
\text { Ad libitum, limited, or restricted energy intake prepartum } \\
\text { Ad libitum, limited, or restricted energy intake prepartum } \\
\text { Ad libitum, limited, or restricted energy intake prepartum } \\
\text { Ad libitum, limited, or restricted energy intake prepartum } \\
\text { Limited energy intake prepartum }\end{array}$ & $\begin{array}{r}13 \\
13 \\
13 \\
5\end{array}$ \\
\hline 2 & Carlson (2006) & $\begin{array}{l}\text { Parturition/very early } \\
\text { lactation } \\
\text { Lactating }\end{array}$ & $\begin{array}{r}2 \\
10\end{array}$ & $\begin{array}{l}\text { Control or L-carnitine supplemented } \\
\text { Control or L-carnitine supplemented }\end{array}$ & $\begin{array}{l}5 \\
5\end{array}$ \\
\hline 3 & Dann et al. (2005) & Ketotic, lactating & 10 to 14 & Ketosis induction, feed restriction & $\begin{array}{r}7 \\
9 ?\end{array}$ \\
\hline
\end{tabular}

\footnotetext{
${ }^{1} \mathrm{DRTP}=$ day relative to parturition.

${ }^{2}$ Dietary treatment descriptions: Dann et al. $(2006)=1$ of 3 levels of energy intake fed prepartum, 150, 100, or 80\% of NRC (2001) requirement for energy for mature cows in late gestation, common lactation diet provided $1.77 \mathrm{Mcal}$ of $\mathrm{NE}_{\mathrm{L}} / \mathrm{kg}$ of $\mathrm{DM}$; Carlson $(2006)=$ either 0 (control) or $50 \mathrm{~g}$ of L-carnitine fed from d -14 to 21 relative to parturition, lactation diet provided $1.68 \mathrm{Mcal}$ of NE $/ \mathrm{kg}$ of DM; Dann et al. $(2005)=$ at 5 DIM cows restricted to $50 \%$ of their ad libitum intake to induce ketosis.

${ }^{3}$ For description of RNA extraction methods for this experiment, see Loor et al. $(2005,2006)$.
}

more attention (Vandesompele et al., 2002; Pfaffl et al., 2004; Gabrielsson et al., 2005; Zhang et al., 2005).

The liver orchestrates the metabolic adaptations that are needed for lactation. As cows transition from pregnancy to lactation, the liver undergoes hypertrophy and gluconeogenesis increases (Bauman, 2000). Metabolic problems that occur during the transition period such as fatty liver can impair liver function, contribute to the development of ketosis (Bobe et al., 2004), and challenge the adaptive capability of the liver. The change in physiological state alone could alter expression of commonly used HKG because of the liver's dynamic role in metabolism. There is the potential for variation in expression of HKG mRNA in studies that evaluate changes in target mRNA copy number in the liver in both nonlactating and lactating cows, and this variation may increase when dietary treatments are imposed. Therefore, the objective of this study was to evaluate the suitability of a number of potential HKG for use in bovine liver studies that included different physiological states, different amounts of feed intake, and different dietary treatments.

\section{MATERIALS AND METHODS}

Samples of liver total RNA from previously conducted experiments (Dann et al., 2005, 2006; Loor et al., 2005, 2006; Carlson, 2006) were selected to create a set of samples $(\mathrm{n}=92)$ that included various physiological states, amounts of feed intake, and dietary treatments for comparison of HKG mRNA stability (Table 1). A survey of the literature was conducted to determine commonly used HKG, which included $\beta$-actin $(\boldsymbol{A C T B})$, glyceraldehyde-3-phosphate dehydrogenase (GAPDH), 18S ribosomal RNA (18S), and peptidylprolyl isomerase A (cyclophilin A; PPIA) as reported by Thellin et al. (1999), Zhong and Simons (1999), Suzuki et al. (2000), and Rhoads et al. (2003). Less commonly used HKG, including $\beta$-glucuronidase (GUSB), polyubiquitin $(\boldsymbol{U B C})$, ribosomal protein S9 (RPS9), and ribosomal protein L32 (RPL32), were suggested by others using either qPCR (Blanquicett et al., 2002) or microarray studies (Zhang et al., 2005; Zhao et al., 2005).

Once candidate HKG were chosen, primers were designed to amplify specific cDNA sequences in each HKG using Primer Express Software v2.0 (Applied Biosystems, Foster City, CA). Sequences, product sizes, and accession numbers are summarized in Table 2. To avoid possible amplification of contaminating genomic DNA, all RNA samples were treated with DNase (DNase I, Qiagen Inc., Valencia, CA) before cDNA synthesis. Additionally, primers sets were designed to fall on or across exon-exon junctions.

Reverse transcription reactions were conducted using $100 \mathrm{ng}$ of total RNA as a template with $50 \mathrm{ng}$ of random hexamers, $50 \mu M$ oligo(dT) $)_{20}, 10 \mathrm{~m} M$ dNTP, $40 \mathrm{U}$ of RNasin (Promega, Madison, WI), and $200 \mathrm{U}$ of SuperScript III reverse transcriptase (Invitrogen, Carlsbad, CA) in a final volume of $20 \mu \mathrm{L}$. To control for variability in cDNA synthesis, 2 separate pools of cDNA were made for each sample. Upon completion of reactions, each cDNA pool was diluted 1:4 using DNase- and RNasefree water. 
Table 2. Primer sets used for the real-time quantitative PCR analysis

\begin{tabular}{|c|c|c|c|c|}
\hline Gene $^{1}$ & Primer $^{2}$ & Sequence $^{3}$ & $\begin{array}{l}\text { Length } \\
\text { (bp) }\end{array}$ & $\begin{array}{c}\text { Accession } \\
\text { number }\end{array}$ \\
\hline$A C T B$ & $\begin{array}{l}\text { ACTB. } 624 \mathrm{~F} \\
\text { ACTB. } 677 \mathrm{R}\end{array}$ & $\begin{array}{l}\text { 5'-GCGTGGCTACAGCTTCACC } \\
\text { 3'-TTGATGTCACGGACGATTTC }\end{array}$ & 54 & AY141970 \\
\hline$G A P D H$ & $\begin{array}{l}\text { GAPDH.276F } \\
\text { GAPDH.335R }\end{array}$ & $\begin{array}{l}\text { 5'-TGGAAAGGCCATCACCATCT } \\
\text { 3'-CCCACTTGATGTTGGCAG }\end{array}$ & 60 & BC102589 \\
\hline$G U S B$ & $\begin{array}{l}\text { GUSB.303F } \\
\text { GUSB.367R }\end{array}$ & $\begin{array}{l}\text { 5'-ATCGGCAGCGCCCACTACT } \\
\text { 3'-CCCTCGTGCTCTAACACATGGAC }\end{array}$ & 65 & CV982833 \\
\hline$U B C$ & $\begin{array}{l}\text { PolyUB.3F } \\
\text { PolyUB.78R }\end{array}$ & $\begin{array}{l}\text { 5'-TGGGTTCCTGTGTCGTCTTG } \\
\text { 3'-TTTGACCTGTGAGTGAATGCGA }\end{array}$ & 76 & AB099083 \\
\hline PPIA & $\begin{array}{l}\text { PPIA. } 204 \mathrm{~F} \\
\text { PPIA.268R }\end{array}$ & $\begin{array}{l}\text { 5'-CTTTCACAGAATAATTCCGGGATT } \\
\text { 3'-CAGTACCATTATGGCGTGTGAAG }\end{array}$ & 65 & BC105173 \\
\hline RPS9 & $\begin{array}{l}\text { RPS9.192F } \\
\text { RPS9.254R }\end{array}$ & $\begin{array}{l}\text { 5'-CCTCGACCAAGAGCTGAAG } \\
\text { 3'-CCTCCAGACCTCACGTTTGTTC }\end{array}$ & 62 & DT860044 \\
\hline RPL32 & $\begin{array}{l}\text { RPL32.92F } \\
\text { RPL32.157R }\end{array}$ & $\begin{array}{l}\text { 5'-AAAGAGGACCAAGAAGTTCATTAGG } \\
\text { 3'-CGCCAGTTCCGCTTGATTT }\end{array}$ & 66 & BC102748 \\
\hline $18 S$ & $\begin{array}{l}18 \mathrm{~S} .1329 \mathrm{~F} \\
18 \mathrm{~S} .1393 \mathrm{R}\end{array}$ & $\begin{array}{l}\text { 5'-TGCATGGCCGTTCTTAGTTG } \\
\text { 3'-AGAGTCTCGTTCGTTATCGGAATT }\end{array}$ & 65 & DQ222453 \\
\hline
\end{tabular}

\footnotetext{
${ }^{1} A C T B=\beta$-actin $; G A P D H=$ glyceraldehyde-3-phosphate dehydrogenase $G U S B=\beta$-glucuronidase $\quad U B C=$ polyubiquitin; PPIA = peptidylprolyl isomerase A (cyclophilin A); RPS9 = ribosomal protein S9; RPL32= ribosomal protein L32; $18 S=18 \mathrm{~S}$ ribosomal RNA.

${ }^{2}$ Primer pairs for ACTB from Loor et al. (2005). Numbers after the gene abbreviation indicate bases in the single-stranded sequence used to design primers; $F=$ forward, $R=$ reverse.

${ }^{3}$ Exon-exon junction for RPL32.157R is underlined and bolded. All primer sequences are written $5^{\prime}$ to $3^{\prime}$. The $3^{\prime}$ notation indicates the starting point for the reverse primer in the single-stranded sequence used to design primers.

${ }^{4}$ GenBank.
}

Real-time PCR reactions were performed in triplicate in 384-well plates using SYBR Green I universal master mix (Applied Biosystems), $400 \mathrm{n} M$ each of the forward and reverse primers (Integrated DNA Technologies, Coralville, IA), and $4 \mu \mathrm{L}$ of diluted cDNA in a final reaction volume of $10 \mu \mathrm{L}$ per well. All 92 samples were run on the same plate, with each of the 2 pools of cDNA occurring on different plates for the same gene. Amplification and data collection were carried out using an ABI Prism 7900 HT SDS instrument (Applied Biosystems) with reaction conditions of $2 \mathrm{~min}$ at $50^{\circ} \mathrm{C}, 10 \mathrm{~min}$ at $95^{\circ} \mathrm{C}$, and 40 cycles of $15 \mathrm{~s}$ at $95^{\circ} \mathrm{C}$ and $60 \mathrm{~s}$ at $60^{\circ} \mathrm{C}$. In addition, dissociation curves were generated following the last cycle. To make standards, pooled liver RNA from several cows and time points was used to make cDNA as described for experimental samples. Serial dilutions were made from this cDNA stock to create a set of standards for the experiment. A standard curve was run for each gene on each plate to determine relative copy number of mRNA (Applied Biosystems, 2001). Data from each pool of cDNA were averaged for each sample within each gene. One sample did not amplify well for any of the 8 genes tested; therefore, its data were removed from the final data set before the HKG were ranked, leaving a final sample size of $n=91$.

Following PCR data collection, a publicly available Visual Basic applet for Microsoft Excel, called geNorm
(Vandesompele et al., 2002), was used to rank the expression variability of HKG in all samples. The procedures outlined in the user's manual (http://medgen.ugent.be/ jvdesomp/genorm/geNorm_manual.pdf) were followed to calculate instability values for gene expression. Expression data calculated with standard curves were imported into geNorm and a measure of expression instability was calculated for all 8 genes. Briefly, geNorm uses an algorithm to calculate all possible pairwise combinations of expression ratios for each gene in each sample. The variation of these pairwise ratios for all samples in the data set is used to calculate a standard deviation, and the arithmetic mean of all pairwise variations for a gene is termed the gene instability value. Genes with stable expression have lower instability values and, therefore, the best rank. In a stepwise fashion, the gene with the largest value was excluded from the data set and the remaining genes were analyzed for a new gene instability measure. This process was repeated until only 2 genes remained.

Because the geNorm program cannot distinguish between the 2 top-ranked genes, bootstrap methodology (Efron, 1982; Boos, 2003; Gabrielsson et al., 2005) was used to determine if one of the top-ranked genes could be consistently ranked above the others. The ranking procedure (use of geNorm program for instability calculations) was bootstrapped by resampling from the origi- 
Table 3. Descriptive statistics for ranks of potential housekeeping genes after 200 bootstrap replications

\begin{tabular}{lccc}
\hline Gene $^{1}$ & $\begin{array}{c}\text { Average } \\
\text { rank }\end{array}$ & $\begin{array}{c}\text { Standard } \\
\text { deviation }\end{array}$ & $\begin{array}{c}\text { Standard } \\
\text { error }\end{array}$ \\
\hline RPS9 & 1.64 & 0.909 & 0.064 \\
GAPDH & 3.27 & 1.409 & 0.099 \\
ACTB & 3.71 & 1.621 & 0.115 \\
GUSB & 4.18 & 1.528 & 0.108 \\
RPL32 & 4.53 & 1.975 & 0.139 \\
18S & 5.35 & 2.236 & 0.158 \\
PPIA & 6.50 & 1.647 & 0.116 \\
UBC & 6.85 & 1.429 & 0.101 \\
\hline
\end{tabular}

${ }^{1} A C T B=\beta$-actin $; G A P D H=$ glyceraldehyde-3-phosphate dehydrogenase; $G U S B=\beta$-glucuronidase $\quad U B C=$ polyubiquitin $; P P I A=$ peptidylprolyl isomerase A (cyclophilin A); RPS9 = ribosomal protein S9; $R P L 32=$ ribosomal protein L32; $18 S=18 \mathrm{~S}$ ribosomal RNA.

nal set of 91 samples to make 200 new data sets. Using this methodology, for each new data set, expression data from a particular sample could have been included a minimum of 0 or maximum of 91 times. Each of these data sets was then imported into the geNorm program and ranked 1 through 8 as described above.

\section{RESULTS AND DISCUSSION}

Preliminary ranking analyses indicated that RPS9, $G A P D H$, and $A C T B$ were the 3 most stably expressed genes across different sample types. Following 200 bootstrap replications, RPS9 was ranked first $59 \%$ of the time, second $23.5 \%$ of the time, and third $14.5 \%$ of the time, making it the most stably expressed gene across samples. Additionally, RPS9 was never ranked below fifth in any of the repetitions. Descriptive statistics for the overall ranks of all genes are summarized in Table 3. Although $G A P D H$ is not usually a very stably expressed HKG (Bustin, 2000), it was the second-highest ranked gene in the group. Because of the clear separation of rankings for RPS9 and other genes, however, we still would be hesitant to conclude that GAPDH is appropriate to use as the only HKG in an experiment. Polyubiquitin $(U B C)$ was the least stably expressed gene throughout, never being ranked first, and ranked last $41.5 \%$ of the time. Densitometry analysis revealed that both PPIA and GAPDH varied widely in liver depending on physiological state and between well-fed or underfed cows (Rhoads et al., 2003). Our results tend to agree with the expression changes for PPIA but to a lesser extent with those for GAPDH; differences in methodologies make it impractical to further compare the 2 studies.

An alternative to using only $1 \mathrm{HKG}$ is to use 2 or more. This methodology has been proposed by Vandesompele et al. (2002) and could offer more control of variability, provided that the HKG chosen are not in pathways that are directly related. Tricarico et al. (2002) also expressed concern with using a single HKG in studies with normal and cancerous human liver and colon tissue. Data from the current study indicate that, for experiments in which samples are taken prepartum, postpartum, or both, and for experiments with dietary treatment groups, RPS9 and GAPDH would be the best combination of HKG. The use of more than one HKG increases the accuracy of sample normalization but also increases the need for monetary and physical resources. For these reasons, we chose to find one stably expressed HKG across experimental types. Other researchers must consider what controls are best for each set of experimental conditions.

The main focus of this experiment was to find the most stably expressed HKG to use for normalization of other target genes. We also evaluated different combinations of genes across sample types to assess the variability in the expression ratios (Figure 1). Figure 1 shows expression ratios of the most stably ranked genes (RPS9 and GAPDH; panel A) compared with the least stable genes (UBC and PPIA; panel B). Clearly, $U B C$ and PPIA are not suitable for use as HKG across different physiological states or different amounts of feed intake because they vary widely between sample groups. Two other commonly used HKG, $18 S$ and $A C T B$, are shown in panel C. Although these plots show less variation than $U B C$ and $P P I A$, they still vary across different categories of samples. Other problems exist with these 2 commonly used genes. High abundance of $18 \mathrm{~S}$ rRNA in samples combined with the sensitivity of real-time qPCR make it difficult to use with less abundant mRNA (Wong and Medrano, 2005). Furthermore, rRNA can be lost during RNA purification steps (Bustin, 2000). The mRNA for ACTB varies in tissues with respect to disease state (Blanquicett et al., 2002; Soyoun and Taeuk, 2003) and fasting (Yamada et al., 1997). Finally, panel D of Figure 1 shows the reduction in variation across sample types when RPS9 (the most stably expressed gene) was used with the least stable gene, $U B C$. Even though the plots are not as uniform as those for RPS9 and GAPDH, the variability across sample types was greatly reduced because of the expression stability of RPS9.

To further illustrate temporal patterns of HKG expression, relative expression of all $8 \mathrm{HKG}$ were plotted (Figure 2) for cows repeatedly sampled across the periparturient period (Loor et al., 2005, 2006; Dann et al., 2006). To eliminate the effects of disease state and because tissue samples were taken only once per cow, the ketotic cows (Dann et al., 2005) were removed from the data set before plotting. Samples from Carlson (2006) also were removed because these cows were not sampled before parturition. Although the overall pattern 
A)

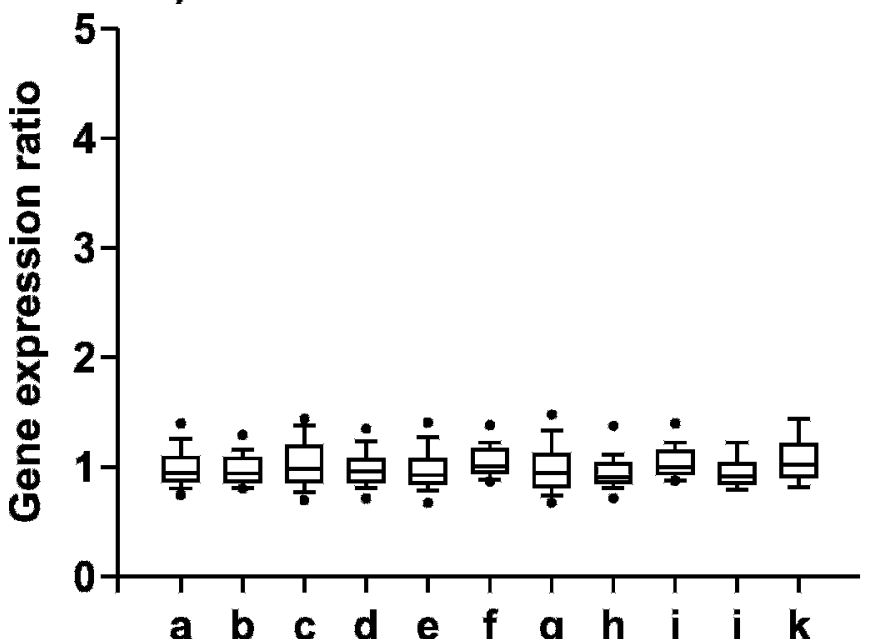

C)

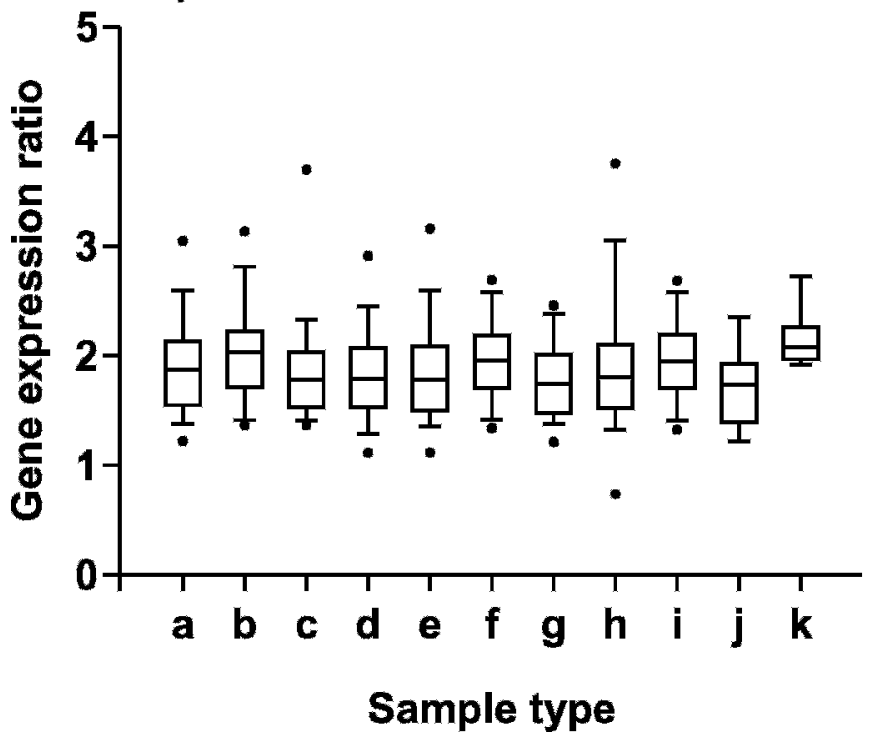

B)

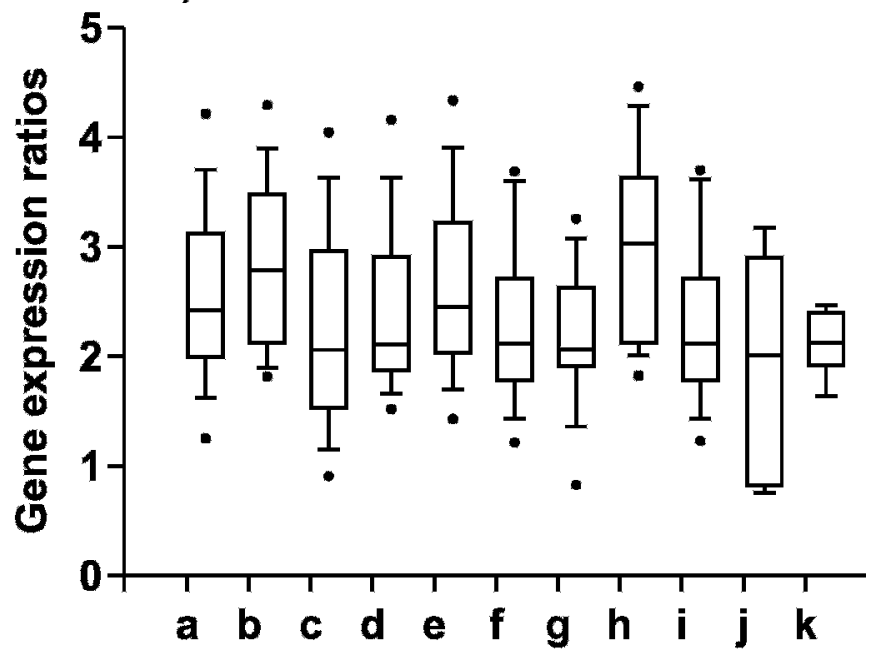

D)

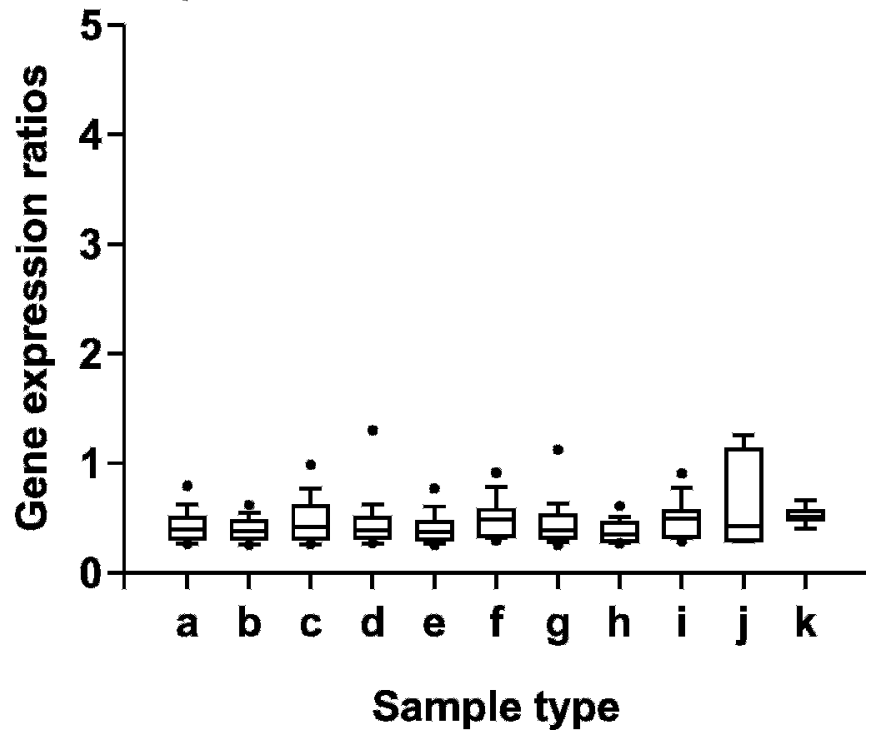

Figure 1. Variation in gene expression ratios across liver samples in different categories when different pairs of housekeeping genes were used. The lower boundary of the box shows the 25 th percentile, the line within the box represents the median, and the upper boundary of the box shows the 75th percentile. The error bars below and above the boxes represent the 10th and 95th percentiles, respectively; outliers are represented by dots. A) ribosomal protein S9 and GAPDH (RPS9/GAPDH); B) peptidylprolyl isomerase A and polyubiquitin (PPIA/ $U B C$ ); C) $18 \mathrm{~S}$ ribosomal RNA and $\beta$-actin (18S/ACTB); and D) ribosomal protein S9 and polyubiquitin (RPS9/UBC). Each panel shows gene expression ratios for the following categories: a) all data points, $\mathrm{n}=91$; b) dry cows, $\mathrm{n}=30$; c) parturition/very early lactation, $\mathrm{n}=18$; d) lactating cows, $n=43$; e) dry or lactating cows fed for ad libitum intake, $n=65$;) dry or lactating cows fed for restricted intake, $n=26$; g) cows with high energy intake prepartum, $\mathrm{n}=30$; $\mathrm{h}$ ) cows with moderate energy intake prepartum, $\mathrm{n}=35$; i) cows with low energy intake prepartum, $n=26 ; j$ ) cows fed a dietary supplement (L-carnitine), $n=6$; and $k$ ) cows with clinical or subclinical ketosis, $n=7$.

across time showed that most of the chosen HKG did not have large increases or decreases (Figure 2), the variation across samples for each gene contributed to the ranking and instability measures originally calculated by geNorm. As shown in Figure 2, the variability in relative expression level in all samples for each time point was smallest for RPS9 and largest for $U B C$. This again supports our findings that RPS9 is a stable gene for use in experiments in which liver samples are taken over time from the same group of cows.

Measuring the stability of HKG mRNA selected for qPCR experiments is important for improving the accuracy of qPCR data. Variability in HKG expression that occurs between different physiological states and under 


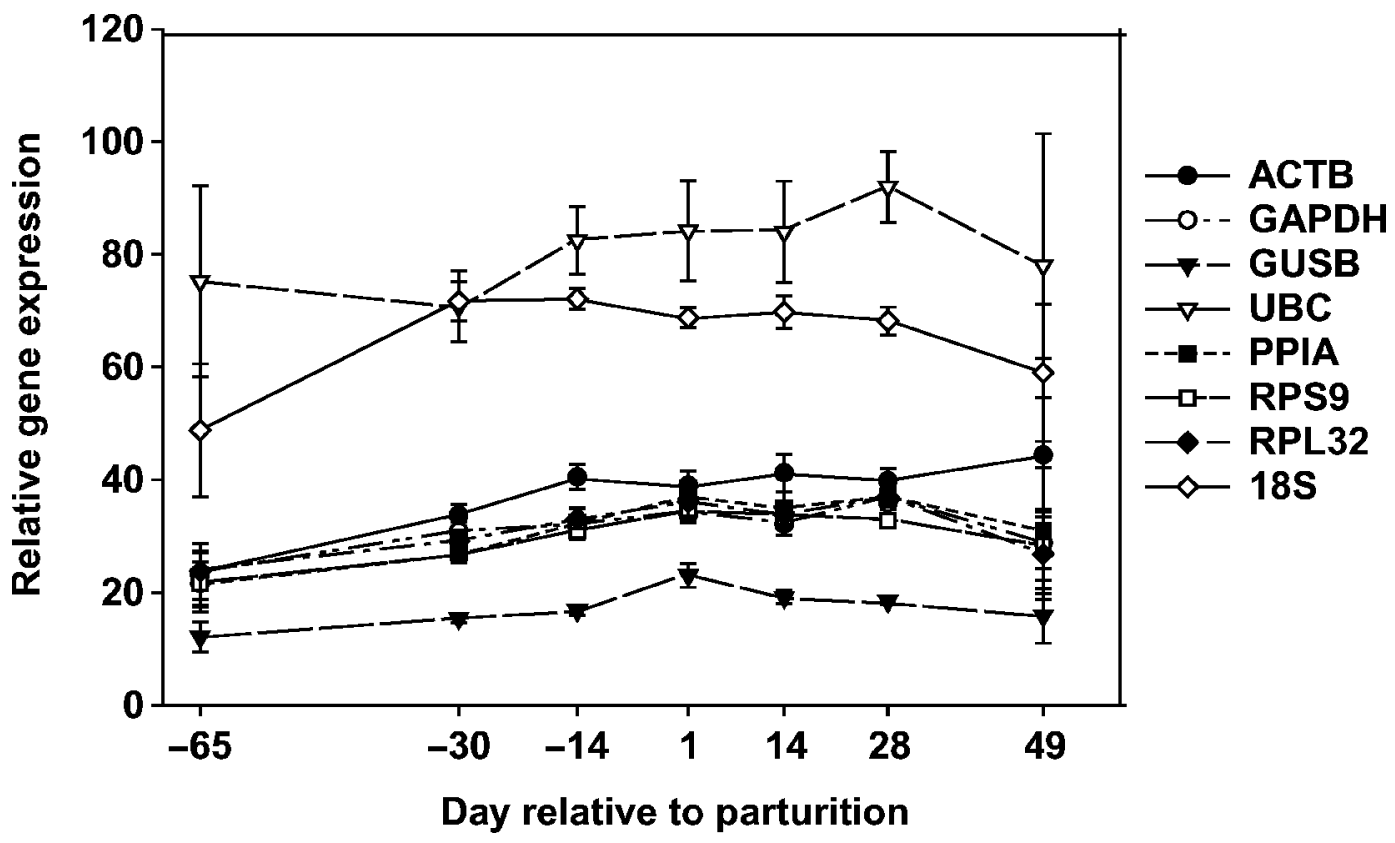

Figure 2. Temporal patterns of gene expression in liver RNA for 8 potential housekeeping genes evaluated using real-time quantitative PCR. Data in the figure are expression values relative to a control sample using a standard curve methodology. Samples were from cows repeatedly biopsied during the periparturient period (Dann et al., 2006; Loor et al., 2005, 2006). Gene names: $A C T B=\beta$-actin; GAPDH = glyceraldehyde-3-phosphate dehydrogenase; $G U S B=\beta$-glucuronidase; $U B C=$ polyubiquitin; $P P I A=$ peptidylprolyl isomerase A (cyclophilin A); RPS9 = ribosomal protein S9; RPL32 = ribosomal protein L32; 18S = 18S ribosomal RNA.

different dietary conditions was demonstrated in this study. We found that RPS9 is a suitable HKG for studies of hepatic gene expression during the periparturient period. Because different tissue types may respond differently to physiological states and dietary conditions, the same set of HKG used in liver may not be stably expressed in other tissues. It is wise, therefore, to confirm expression stability for HKG before data collection begins.

\section{ACKNOWLEDGMENTS}

The authors greatly appreciate the assistance provided by R. Oliveira and C. A. Green regarding experimental protocols and testing of primer sets. Special thanks are extended to D. Rincker, R. Ebert, and M. Raczkowski for assistance with data analysis.

\section{REFERENCES}

Applied Biosystems. 2001. User Bulletin \#2 ABI PRISM 7700 Sequence Detection System. http://docs.appliedbiosystems.com/ pebiodocs/04303859.pdf Accessed Sept. 11, 2006.

Bauman, D. E. 2000. Regulation of nutrient partitioning during lactation: Homeostasis and homeorhesis revisited. Pages 311-328 in Ruminant Physiology: Digestion, Metabolism, Growth, and Reproduction. P. B. Cronje, ed. CABI Publishing, Cambridge, MA.

Blanquicett, C., M. R. Johnson, M. Heslin, and R. B. Diasio. 2002. Housekeeping gene variability in normal and carcinomatous colo- rectal and liver tissues: Applications in pharmacogenomic gene expression studies. Anal. Biochem. 303:209-214.

Bobe, G., J. W. Young, and D. C. Beitz. 2004. Pathology, etiology, prevention, and treatment of fatty liver in dairy cows. J. Dairy Sci. 87:3105-3124.

Boos, D. D. 2003. Introduction to the bootstrap world. Stat. Sci. 18:168-174.

Bustin, S. A. 2000. Absolute quantification of mRNA using real-time reverse transcription polymerase chain reaction assays. J. Mol. Endocrinol. 25:169-193.

Bustin, S. A. 2002. Quantification of mRNA using real-time reverse transcription PCR (RT-PCR): Trends and problems. J. Mol. Endocrinol. 29:23-39.

Carlson, D. B. 2006. L-Carnitine supplementation for periparturient dairy cows. PhD Diss. Univ. Illinois, Urbana.

Dann, H. M., N. B. Litherland, J. P. Underwood, M. Bionaz, A. D'Angelo, J. W. McFadden, and J. K. Drackley. 2006. Diets during far-off and close-up dry periods affect periparturient metabolism and lactation in multiparous cows. J. Dairy Sci. 89:3563-3577.

Dann, H. M., D. E. Morin, G. A. Bollero, M. R. Murphy, and J. K. Drackley. 2005. Prepartum intake, postpartum induction of ketosis, and periparturient disorders affect the metabolic status of dairy cows. J. Dairy Sci. 88:3249-3264.

Efron, B. 1982. The jackknife, the bootstrap and other resampling plans. Soc. Industrial Appl. Math., Philadelphia, PA.

Gabrielsson, B. G., L. E. Olofsson, A. Sjögren, M. Jernås, A. Elander, M. Lönn, M. Rudemo, and L. M. S. Carlsson. 2005. Evaluation of reference genes for studies of gene expression in human adipose tissue. Obes. Res. 13:649-652.

Loor, J. J., H. M. Dann, R. E. Everts, R. Oliveira, C. A. Green, N. A J. Guretzky, S. L. Rodriguez-Zas, H. A. Lewin, and J. K. Drackley. 2005. Temporal gene expression profiling of liver from periparturient dairy cows reveals complex adaptive mechanisms in hepatic function. Physiol. Genomics 23:217-226.

Loor, J. J., H. M. Dann, N. A. Janovick Guretzky, R. E. Everts, R. Oliveira, C. A. Green, N. B. Litherland, S. L. Rodriguez-Zas, H. 
A. Lewin, and J. K. Drackley. 2006. Plane of nutrition prepartum alters hepatic gene expression and function in dairy cows as assessed by longitudinal transcript and metabolic profiling. Physiol. Genomics 27:29-41.

NRC. 2001. Nutrient Requirements for Dairy Cattle. 7th rev. ed. National Academy Press, Washington, DC.

Pfaffl, M. W., A. Tichopad, C. Prgomet, and T. P. Neuvians. 2004. Determination of stable housekeeping genes, differentially regulated target genes and sample integrity: BestKeeper-Excel-based tool using pair-wise comparisons. Biotechnol. Lett. 26:509-515.

Rhoads, R. P., C. McManaman, K. L. Ingvartsen, and Y. R. Boisclair. 2003. The housekeeping genes GAPDH and cyclophilin are regulated by metabolic state in the liver of dairy cows. J. Dairy Sci. 86:3423-3429.

Soyoun, K., and K. Taeuk. 2003. Selection of optimal internal controls for gene expression profiling of liver disease. Biotechniques $35: 456-460$

Suzuki, T., P. J. Higgins, and D. R. Crawford. 2000. Control selection for RNA quantitation. Biotechniques 29:332-337.

Thellin, O., W. Zorzi, B. Lakaye, B. De Bornam, B. Coumans, G. Hennen, T. Grisar, A. Igout, and E. Heinen. 1999. Housekeeping genes as internal standards: Use and limits. J. Biotechnol. 75:291-295.

Tricarico, C., P. Pinzani, S. Bianchi, M. Paglierani, V. Distante, M. Pazzagli, S. A. Bustin, and C. Orlando. 2002. Quantitative real- time reverse transcription polymerase chain reaction: Normalization to rRNA or single housekeeping genes is inappropriate for human tissue biopsies. Anal. Biochem. 309:293-300.

Vandesompele, J., K. De Preter, F. Pattyn, B. Poppe, N. Van Roy, A. DePaepe, and F. Speleman. 2002. Accurate normalization of realtime quantitative RT-PCR data by geometric averaging of multiple internal control genes. Genome Biol. 3:research0034.10034.11.

Wong, M. L., and J. F. Medrano. 2005. Real-time PCR for mRNA quantitation. Biotechniques 39:75-85.

Yamada, H., D. Chen, H.-J. Monstein, and R. Håkanson. 1997. Effects of fasting on the expression of gastrin, cholecystokinin, and somatostatin genes and of various housekeeping genes in the pancreas and upper digestive tract of rats. Biochem. Biophys. Res. Commun. 231:835-838.

Zhang, X., L. Ding, and A. J. Sandford. 2005. Selection of reference genes for gene expression studies in human neutrophils by realtime PCR. BMC Mol. Biol. 6:4.

Zhao, S.-H., J. Recknor, J. K. Lunney, D. Nettleton, D. Kuhar, S. Orley, and C. K. Tuggle. 2005. Validation of a first-generation long-oligonucleotide microarray for transcriptional profiling in the pig. Genomics 86:618-625.

Zhong, H., and J. W. Simons. 1999. Direct comparison of GAPDH, $\beta$-actin, cyclophilin, and $28 \mathrm{~S}$ rRNA as internal standards for quantifying RNA levels under hypoxia. Biochem. Biophys. Res. Commun. 259:523-526. 